\title{
NARRATÍV SZEMLÉLET A SEGÍTŐ KAPCSOLATBAN
}

\author{
Szerzők: \\ Bojti István \\ Integratív Medicina Kft. \\ Schéder Veronika \\ Debreceni Egyetem
}

\section{Lektorok:}

Madácsi Mária
Nyíregyházi Főiskola
Hüse Lajos
Debreceni Egyetem

Kondé Zoltánné Inántsy-Pap Judit

Debreceni Egyetem

Első szerző e-mail címe: ungvar35orvos@gmail.com
Koncz István

Professzorok az Európai Magyarországért Egyeület

Bojti István (2015): Narratív szemlélet a segítő kapcsolatban. Különleges Bánásmód, I. évf. 2015/2. szám, 59-70. DOI 10.18458/KB.2015.2.59

\begin{abstract}
Absztrakt
A szerzők a narratív szemléletben egy nagyon rugalmas gondolkodási keretet mutatnak be, ami nemcsak a segítö kapcsolatok széles skálájában, de akár a magánéletben is alkalmazható. Tárgyalják a narratív pszichológia alapját képezö posztmodernista és konstruktivista modellt. Három esetet használnak fel a módszer lehetöségeinek bemutatására. Az elsö esetben a viselkedés hátterében rejlö narratíva könnyen feltárható és egyszerü módon megváltoztatható, ezáltal a probléma megoldható. A második eset bonyolult problémát képez, és itt a narratív pszichoterápia eszközei kerülnek bemutatásra. Külön kiemeljük ebben a nyelvi eszközök tudatos felhasználását. A harmadik eset azt illusztrálja, hogy a problémák hátterében többféle narratíva lehetséges, és a megfelelö narratíva kiválasztása a megoldások lehetöségét is meghatározza. A narratívák választásakor a személy saját sorsát formálja meg, melyért felelösséggel tartozik.
\end{abstract}

Kulcsszavak: segítő kapcsolat, posztmodern, konstruktivizmus, narratíva, externalizálás

Diszciplina: pszichológia

\begin{abstract}
NARRATIVE APPROACH IN THE HELPING RELATIONSHIPS

The authors present a very flexible cogitative framework by using the narrative approach, which can be applied not only in a wide range of helping relationships, but also in private life. They discuss the postmodern and the constructivist model which form the basis for the narrative psychology. Three cases are presented to demonstrate the potential of the method. In the first case, the narrative behind the behaviour is easily detectable and can be altered in a simple manner, thus the problem can be solved. The second case encompasses a complex
\end{abstract}


problem, and the instruments of the narrative psychotherapy are presented here. The authors here emphasised the thoughtful use of linguistic instruments. The third case illustrates the possibility of multiple narratives for the underlying problems, and that choosing the right narrative determines the possibility for solutions. A person creates his/her own destiny when choosing the narratives, for which he/she bears the responsibility.

Keywords: helping relationship, postmodern, constructivism, narrative, externalization

Discipline: psychology

A társadalom gyorsuló ütemben változik. Az információtechnológia robbanása, a globalizált kultúra, a tekintély átalakulása, az egzisztenciális bizonytalanság, munkanélküliség, bevándorlók - olyan fogalmak, amikről egy emberöltővel ezelött alig hallottunk még. Hol van már a békebeli szexuálneurózis, amiből Freud felépítette a személyiségmodelljét? Ha a társadalom változik, a segítő kapcsolatnak is változnia kell. Vajon érvényesek-e a korábbi elméletek az új kihívások esetében? Hogyan lehet a segítőknek a rendkívül összetett új típusú problémákat követniük? Ma már nem a kliensek helyét kell az elméleti rendszerekben megtalálni, hanem az elméleteket kell a kliensekhez igazítani. Mindenki különleges bánásmódot igényel.

Terápiás gyakorlatunkban a posztmodern narratív pszichológia lehetőségeiben hatékony eszközöket találtunk, amelyekkel rugalmasan reagálhatunk a kliens problémájára.

\section{A posztmodernizmus}

A sokféleség kezeléséhez a posztmodernizmus megfelelő keretet jelent. Kialakulása a modernizmus elégtelenségére adott válasz volt.

A modernista gondolkodás a felvilágosodással kezdte diadalútját, az ipari forradalom, a napjainkban is tartó tudományos, technikai haladás hátterét adja. Alapszemlélete a megelöző korszak mitikus gondolkodásával szemben az, hogy a természet és a társadalom a maga teljes objektív valóságában megfelelő tudományos módszerekkel megismerhető, ez csak idő és források kérdése. Miután a valóság összes vonatkozása megismerszik, nyilván a helyes válaszok is megszületnek. A modernizmus az emberiség életminőségének korábban elképzelhetetlen javulásához vezetett (Wilber, 2009).

Bár a modernizmus alapvetése kétségtelenül logikus, egyre több viszonylatban derült ki, hogy mégsem érvényes. A fizikában a Heisenberg-féle bizonytalansági relációra, vagy a modellfüggő realitás elméletére utalok (Hawking és Mlodinov, 2011). Mindkét elmélet elvileg zárja ki a valóság objektív megismerhetőségét. A társadalomtudományok mindegyikéről elmondható az, hogy a kutatók hipotéziseit, a használt fogalmakat, módszereket a kutatók kulturális környezete meghatározza. Ezek a körülmények a kutatott jelenségnek általában nem részei, viszont a megállapításokban szükségszerüen visszaköszönnek (László, 2005). Az irodalomtudomány nagyon szépen fejezi ki a valóság variábilis jellegét, amikor azt állítja, hogy az irodalmi mü a befogadóban keletkezik (Bókay, 2006). Még a teológiában is találunk olyan állítást, hogy „Isten (...) ember elötti önmegnyilvánulása már függ attól, ahogyan az ember felfogja ezt a megnyilvánulást” (Tillich, 2002, 64. o.). A müvészi alkotásoknak pedig egyenesen fő témája éppen az a dráma, amit a valóság eltérő értelmezése jelent. Itt most kapcsolódóan csak Martin Scorsese Kazantzakis regénye alapján készült Krisztus utolsó megkísértése címü filmjére utalok. 
Mi adja a posztmodernizmus lényegét? A fenti példák mindegyikében közös az a tétel, hogy a valóság a maga objektív minőségében nem ismerhető meg. A megismerés aktusa maga befolyásolja a valóságot, valamint a megismerő szubjektuma befolyásolja a valóságról nyert mentális reprezentáció tartalmát (Goldenberg és Goldenberg, 2008). A posztmodernizmus tehát elutasítja azt a modernista állítást, hogy a valóság megfelelő módszerekkel teljesen megismerhető.

Ennek az alapállásnak több következménye van. Elöször is lemond a végső valóság megismerésének lehetőségéről, ami egyet jelent azzal, hogy elfogadja, hogy egymással párhuzamosan több, esetleg egymást kizáró valóságértelmezések érvényesek lehessenek. Mivel nincs egységes, mindenre érvényes elmélet, ezért a sokféleség természetes állapot, ami a sokféleség toleranciáját tételezi. A sokféle értelmezés jogossága bátorítja az egyéni szabadság nagyobb mértékü kiteljesítését. Ez az uralkodó felfogás kritikáját vonja maga után. A hagyományok háttérbe szorulnak, a nagyobb felelősség pedig előtérbe kerül.

\section{A narratív pszichológia}

A posztmodernizmus természetesen a pszichológiában is megjelent. Az egyik legismertebb ilyen rendszer a narratív pszichológia. A narratíva szó történetet jelent, egy nyelvi képződményt, alapjelentésében valamilyen időbeli eseménysor kezdettel, kibontakozással és befejezéssel (László, 2005). Például egy történet:

Amikor a szomszédomnak a karja zsibbadt, végül kiderült, hogy szívinfarktusa volt. Kórházban feküdt hetekig, megrokkanva jött haza és egy év múlva egy második infarktusban meg is halt.

A narratív pszichológia a történetet nemcsak egy konkrét eseménysorként, hanem ettől tágabban is értelmezi. A gondolkodásnak arra a sajátosságára utal, hogy a személynek a környezetére és a saját magára vonatkozó fontos tudása jellemzően történetekből eredeztethető. Ezek együttesen egy szubjektív élettapasztalattá állnak össze, mely a narratíva szó tágabb jelentése. Ebben az értelemben egy-egy narratíva formailag akár már nem is tekinthetö történetnek, hanem inkább valamilyen tapasztalaton alapuló vélekedésnek, vagy társadalmi normának, és a mögöttes konkrét történetek már homályba vesztek (Payne, 2014). A fenti példa mögött álló élettapasztalat narratívát a következőképpen lehet megfogalmazni:

Az ember életét mindenféle betegség veszélyezteti, jó lesz vigyázni.

Minden narratívára igaz, hogy a benne rejlö tudás eredete szubjektív, töredékes, valamilyen események személyes értelmezéséből származik. Minden narratíva lehetne más is. Ellentéte az „objektív” tudás, amely tudományos igényü vizsgálatok hozadéka (Payne, 2014).

Nemcsak az egyes egyének gondolkodása narratív jellegü, a különböző embercsoportoknak, a társadalomnak, egy-egy civilizációnak is vannak közös narratívái (erkölcs, értékek, szokások stb.). Ezeket a közös narratívákat diskurzusoknak is szokták nevezni, utalva csoportos jellegükre. Könnyen belátható, hogy a különböző narratívák hierarchiát alkotnak, illetve sok konfliktus értelmezhető a narratívák harcaként (Kecskeméti Molnár, 2004).

\section{A konstruktivizmus}

Annak érdekében, hogy az emberek biztonságosan eligazodjanak a világban, mindenki megpróbál a fontos tapasztalatainak valamilyen jelentést adni. Fontos körülmény, hogy a személy számára kevésbé az eredeti tapasztalat a lényeges, sokkal inkább az, hogy milyen jelentést tulajdonít neki (Goldenberg és Goldenberg, 2008). Például ha valakinek zsibbad a karja, egészen másként reagál akkor, ha azt fáradtságnak, mint ha szívinfarktusnak tulajdonítja. A valóságnak ez az értelmezése gyakran evidenciaérzéssel jár, holott pusztán egy mentális konstrukcióról van szó. Könnyü összetéveszteni a valóságot a róla alkotott 
konstrukcióval. Erre a helyzetre közismert a térkép és a táj metaforája (O'Connor és Seymour, 1996). A konstruktivista felfogás szerint a megismerés folyamatában a valóságról alkotott minden tudásunk csak konstrukció, ami töredékes, és biológiai, pszichológiai, kulturális hatások által befolyásolt.

A személyes és a társadalmi narratívák, valamint a tapasztalatokat értelmező konstrukciók között szoros összefüggés van. A narratívák együttese felfogható egy keretként, amelybe az egyén a konkrét tapasztalatait beilleszti, és a kerettel összhangban alkotja meg értelmező konstrukcióit. Természetesen párhuzamosan több különböző narratívát egyaránt érvényesnek tekinthetünk, amelyek ugyanazon valóság különböző konstrukcióihoz vezetnek (Payne, 2014).

Amennyiben a narratívákat az egyéni konstrukciók megalkotásának kereteként definiáljuk, úgy a nyelv nevezhető a konstrukciók hordozó közegének, „ruhájának”. Ahhoz, hogy a narratívák, illetőleg az értelmező konstrukciók kommunikálhatóvá váljanak, nyelvi jelleget kell ölteniük. A nyelvi rendszer keretei azonban mindig szegényebbek, szükebbek, avagy egyszerüen csak mások, mint a narratívákéi. Ez gyakori oka lehet a kommunikáció zavarainak a segítő kapcsolatokban. A segítő kapcsolatok csatornája ugyanis elsődlegesen a nyelvhasználat.

A szó, amely megnevez valamit, mindig három összetevő kapcsolata. Ez a három összetevő: a jelölő (azaz a hangalak), a jelölt (azaz a jeltárgy, a denotátum) és a beszélő/hallgató személye (Tolcsvai, 2002). A szavak elsődleges jelentését mindig a jelölő és a jelölt közötti közmegegyezésen alapuló kapcsolat adja. A jelölők és a jelentések közötti kapcsolat azonban többféle lehet. Szavaink többségének nem egy, hanem több jelentése is van. Előfordul, hogy ezek a különböző jelentések összefüggenek egymással (poliszémia), de az is lehet, hogy azonos alakhoz más-más jelentés társul (homonímia). A magyar anyanyelvüek ráadásul sokszor tulajdonítanak új jelentéseket egy-egy régi kifejezésnek - ez az egyik legtermékenyebb szóalkotási módunk. Ennek föként az az oka, hogy mindig több megneveznivalónk akad, mint ahány szó ezeknek a tartalmaknak a kifejezésére a rendelkezésünkre áll. A szó teljes, a beszélő és a hallgató számára értelmezett jelentésében ezen kívül egyéb jelentésfajták is megmutatkoznak. A konnotatív jelentés pl. a denotatívhoz valamilyen egyéni vagy közösségi értékrend/tudás alapján hozzárendelt képzettársításos jelentés: a csavar szó mást jelent egy müszerésznek, mást egy fodrásznak, egy jégtáncosnak stb. Az érzelmi jelentés a beszélő érzelmeit jelöli, ami leginkább a hangsúlyban, hanglejtésben, ill. a szóválasztásban mutatkozik meg (pl. ha azt mondom: Te csibész! - ebben az esetben a csibész szó használata részemröl kedveskedés).

A narratívák és konstrukciók megfelelő nyelvi formába öntése mind a kliens, mind a terapeuta számára bonyolult feladat, hiszen az érzelem maga, ami a narratívák és konstrukciók táptalaja, „túl van a szavakon”. A világot azonban az anyanyelveink által lefektetett irányvonalak mentén elemezzük - a közismert Sapir-Whorf hipotézis szerint a nyelv befolyással van arra, hogyan érzékelünk és emlékezünk, meghatározza a gondolkodásunkat (Crystal, 2003).

\section{A narratív gondolkodás a gyakorlatban}

A narratív szemléletű gondolkodás jellemzője tehát, hogy bár minden érintett tapasztalatainak a forrása azonos lehet, az eseményeknek mégis meglepően különböző jelentést tulajdoníthatnak. Ezért a segítö kapcsolatban különösen fontos, hogy a tapasztalatok személyes jelentését megismerjük.

A kliensek problémával kapcsolatos releváns történetei általában könnyen megismerhetőek, elég rákérdezni. Ezt követően a narratív szemléletü segítő kommunikáció a kliens narratíváját felhasználja az ellátás során, arra választ ad, hiszen a kliens elégedettsége alapvetően függ 
attól, hogy a saját problémájára választ kapott-e. Sok esetben valamilyen egyszerü intervencióval, például informálással, edukációval megnyugtató megoldás születik. A kommunikációnak ezt a formáját közvetlen vagy explicit kommunikációnak nevezzük (Schulz, 2012 - vö.: 1. esetbemutatás).

A narratívák más része azonban csak részben, vagy egyáltalán nem tudatosul a személyben, viszont annál nagyobb hatású a gondolkodására. A tapasztalatok széles körére kiterjed, a jelentésadó mentális folyamatokat konzekvensen valamilyen maladaptív irányba befolyásolja, egy beszükült világot teremt a kliens számára (Payne, 2014). Ezeket a narratívákat nemcsak azonosítani nehéz, de a megváltoztatásuk is erőfeszítést igényel. Az edukáció általában nem elegendő. Az ilyen narratívák tehát csak implicit módon jelennek meg a kommunikációban, észlelésük és értelmezésük a segítőtől többszempontú elemzést kíván.

Ezek a kliens gondolkodását alapvetően befolyásoló narratívák, amelyek már a tudatos gondolkodás határain kívülre kerültek, önálló tudattartalom entitásukat elveszítették. Azaz a személy ezeket egy érzelmi beállítódásnak, a gondolkodás alaptónusának érzékelné, ha a figyelmét erre irányítaná. A narratíva határai sem érzékelhetőek, mindent áthat. Nem is nyelvi karakterü ez a tudattartalom, mert nem lehet megnevezni, a hatása pedig nem szavakban érvényesül. A fenti karzsibbadással kapcsolatos eset példájában ezt valamilyen lebegö félelemnek, a testi érzésektől való riadalomnak próbálhatjuk meg leírni.

A narratívának ez a minősége érthetővé teszi, hogy a szokásos gondolkodás számára megfoghatatlan, így kezelhetetlen. A logikus érvelés hatástalan rá. A tapasztalatok igen nehezen befolyásolják, hiszen nem a tapasztalatok vannak a narratívára hatással, hanem fordítva, a narratíva adja meg a tapasztalatok jelentését. A merev, maladaptív viselkedés hátterét ez a modell értelmezhetővé teszi (2. esetbemutatás).

A narratív szemléletü intervenció meghatározó mozzanata az, hogy a fenti diffúz lelki tartalmat a nyelv segítségével azonosítjuk, más lelki tartalmaktól elhatároljuk. Ez a gyakorlatban azt jelenti, hogy a kliens bizonyos tulajdonságait, késztetéseit, gondolatait hozzárendeljük, és névvel látjuk el. Fontos, hogy a segítő saját nyelvhasználatát a klienshez igazítsa. J. L. Austin az ún. beszédaktus-elméletben fogalmazta meg elöször azt, hogy egyes megnyilatkozások nem csupán információt közvetítenek, hanem cselekvésértékük van. Az ilyen típusú közlések valamilyen új pszichológiai vagy társadalmi realitást eredményeznek (Crystal, 2003). A névadással egy, a kliens tapasztalataival koherens új entitás jön létre, a szavak valami fontos újat teremtettek. Korábbi esetünket követve az új entitásnak lehetne a neve Félelem. Félelem fő üzenete az, hogy az élet fenyegető, Te esendő vagy, és bármikor baj érhet. Ez az új entitás a hétköznapi gondolkodás számára könnyebben kezelhető. Plasztikus metaforája lehet egy személyiségrész. Tovább segíti az új entitással való munkát az, hogy a szándékai, a hatásmódja, a története a kliens számára énközeli, hiszen minden mozzanatban a saját lelki tartalmaiból építkeztünk. Nem utolsósorban az új entitás elkülönül az egyéntől, mintegy külsővé lesz, és bünbakká válhat. Azaz elhordozza a problémákért a felelösséget. Ezért az intervenció elterjedt elnevezése az externalizáció. Nem az ember a probléma, hanem a probléma a probléma (Kecskeméti Molnár, 2004). Ez a hatás a felelősség szempontjából körültekintést igényel a segítő részéröl, de a büntudat által bénított depressziós kliensek esetében nagyon pozitív lehet.

A segítő folyamat további részében ez a korábban beazonosíthatatlan és elérhetetlen tudattartalom externalizálva a gondolkodás reflektorfényébe kerül. Részletes elemzésnek, értelmezésnek vethető alá, melynek során az evidens állítások megkérdőjeleződnek, ellentmondásosságuk kiderül, a részletező perspektívában differenciálódnak, azaz dekonstruálódnak. Az új alternatívák kidolgozása és kipróbálása a rekonstrukció folyamata, aminek során átalakul egy remélhetőleg adaptív viselkedés motivációjává (Prochaska és Norcross, 2011). 
Külön kiemelést érdemel, hogy a személy a narratívák révén nemcsak jelentést ad a tapasztalatainak, hanem az adott jelentés alapján alakítja is a viselkedését. Végeredményben tehát a narratívák a jövőre is irányulnak, és teremtik a valóságot. Tekintettel arra, hogy mindenkinek van valamilyen mértékü választási lehetősége arra, hogy milyen narratívákat alkosson a világról, végeredményben így mindenki alkotója a saját világának. A szabadság felelősséggel jár (Yalom, 1978). Lehetőleg előrevivő narratívákat kellene alkotni, amelyek jó programot kínálnak a probléma meghaladásához. A problémákkal küzdő személyek narratívái ezzel szemben tehetetlenséget sugallnak (3. esetbemutatás).

\section{A segítő narratívái}

A narratív szemlélet sajátossága, hogy nemcsak a kliens, hanem a segítő narratíváit is tekintetbe veszi. Bár magától értetődik, hogy a segítő lelki munkamódja alapjaiban megegyezik a kliensével, a segítő önreflexiója mégis gyakran háttérbe szorul, ezért különös figyelmet igényel. A szimmetrikus alapállásból következik, hogy a narratív szemléletü segítő kapcsolat nem az alá-fölérendeltséget hangsúlyozza, hanem a klienst a saját élete, a segítőt pedig a saját szakmája szakemberének tartja. Ennek a kétfajta mellérendelt szakértelemnek az együttműködésétől várja a probléma megoldását.

A segítő releváns narratívái számos témában jelenhetnek meg, mellyel Bálint Mihály részletesen foglalkozott az orvos apostoli funkciója fogalom megalkotásakor és elemzésekor (Bálint, 1990). Csak néhány fontosabbat említünk meg az alábbiakban:

A személyes szakmai tapasztalatok nyilvánvaló értéket jelentenek. Ezek a tapasztalatok a narratívák olyan együttesét jelentik, amik a segítő látásmódját döntően befolyásolják. Ebből eredően azonban fennállhat a veszélye az elöítéletességnek, a sematikus, redukcionista problémakezelésnek.

A segítök képzésük során különféle szakmai elméleteket tanulnak meg, melyek a problémákat kategorizálják, értelmezik, prognosztizálnak, és a kezelés módját lefektetik. Az ember hajlamos e tekintélyszemélyek által is bebetonozott tételekre evidenciaként tekinteni, pedig mindegyik elmélet csak egy modell, korlátozott érvényességi tartománnyal. Egy konstrukció, nem pedig maga a valóságos folyamat.

Ugyancsak fontosak azok a narratívák, amik a társadalom szokásos gyakorlatára vonatkoznak, és ezekkel könnyü a segítőnek azonosulni. Például hagyományok, etikai álláspontok, viselkedési szabályok tartoznak ide.

Tágan értelmezve a segítő munkahelyének is vannak közös narratívái, melyben a dolgozók osztoznak. Például a munkamegosztás, a konzultáció szabályai, a segítő kapcsolat helyi értelmezése és egyéb szokások. Ezek a segítő munkának nagyon fontos keretfeltételei, amikre adottságként szoktunk tekinteni. Holott csupán egy csoport konstrukciói, és minden eleme másképp is lehetne.

Az előzőekben a segítő munka olyan szilárd alapvetéseit kérdőjeleztük meg, mint a személyes szakmai tapasztalatok, az elméleti megalapozás, a kulturális feltételek, a munkahelyi kultúra. Mindezeket a valóság érvényes leírása helyett csak konstrukcióknak tekintjük, ugyanúgy, mint a kliensek narratíváit. Milyen nyereség származik ebböl? Egy szélsőséges relativizmus inkább bénító hatású lehet.

Elöször is, bár a narratív szemlélet elismeri, hogy minden lehetne másként is, ez nem jelenti azt, hogy ne lennének sokszorosan bevált jó konstrukciók, amikhez érdemes ragaszkodni. Csak annyit jelent, hogy a segítő nyitott arra, hogy ezeket a konstrukciókat felülvizsgálja. Ezzel nagy felelősséget vállal, hiszen biztonságosabb a hagyományokhoz igazodni, mint azokat mérlegelni. 
A saját beállítódások narratívaként észlelése a segítőt rugalmassá teszi, a klienshez jobban tud alkalmazkodni. A rugalmasságból ered, hogy kevesebb konfliktussal találkozik, ezért kisebb a kiégés veszélye.

A posztmodernizmus hozadéka az a felismerés, hogy a segítő sohasem ismerheti meg a klienst és környezetét a maga valóságában, azért, mert ebben puszta jelenlétével változást idéz elő és a részévé válik. Tehát az a karteziánus beállítódás, hogy a külsős szakember megvizsgálja a helyzetet, megérti, majd a megoldást kigondolja és megtanítja a klienssel, ebben a keretben nem lehet érvényes. Ehelyett a segítő folyamatot a segítő és a kliens narratíváinak egyeztetéseként, kölcsönös egymásra hatásaként, a közös narratíva megtalálásaként értelmezi (Launer, 2002). E szemlélet talán segít abban, hogy az esetek növekvő hányadában sikerüljön a problémákra kielégítő megoldást találni.

\section{1. esetbemutatás}

Az 5 éves Noémi szülei válását követően enurezis tüneteivel lovasterápiás kezelésben részesült. 3 hónap után tünetmentesen hagyta el a terápiát (ezalatt heti 1 alkalommal 30 perces foglalkozásokon vett részt), de újabb fél év elteltével visszaesett. Édesanyja szerény, kicsit szorongó alkatú asszony, lánya a kisebbik gyermeke. A lovasterápiás foglalkozásokon korábban nagyon jó kapcsolatunk alakult ki, nemcsak Noémivel, hanem az édesanyjával is. Rendszeresen utolsóként jöttek, a ló gondozására még ottmaradtak, és olyankor fontos dolgokról beszélgettünk. Az újabb terápia csak néhány hétig tartott, eredményesnek látszott és a befejezését terveztük. Érezhető volt, hogy az édesanyát valamiért aggasztja a terápia közeli befejezése. Új problémát hozott szóba, és a tervezett utolsó órára Noémi visszaesett. Rákérdeztünk a félelmeire. Kiderült, hogy egyrészt attól tart, hogy a lovasterápiás kezelések nélkül a kislány tünetei újra jelentkezni fognak (ami immár be is következett), és ezt az állapotot egyedül nem fogja tudni kezelni. Másrészt bevallottan neki magának is nagyon sokat jelentettek ezek a foglalkozások, a tartalmas közös beszélgetéseink, és most ezt is elveszni látja.

Átéreztük a félelmeit. Megerősítettuik az édesanyát, hogy nekünk is fontos volt a közöttünk kialakult kapcsolat, és nem ragaszkodunk ahhoz, hogy hirtelen megszakítsuk. Megállapodtunk abban, hogy 3 hetente még továbbra is fogunk találkozni, annyi alkalommal, ahányszor ezt ő szükségesnek tartja. Ha Noémi tünetei kiújulnának, akkor várhatóan azok már csak hamar múló panaszok lesznek. (Példaként hoztuk fel a korábban is megtapasztalt sikereket, nem pedig a kudarcokat.) Láthatóan mindenki elégedett volt ezzel a megállapodással, és megkönnyebbülve váltunk el egymástól.

Összesen kétszer jöttek még el, több találkozást nem igényeltek. A bemutatott esetben az édesanya és a lánya a terápia végére szorongóvá vált. Ezt burkoltan fejezték ki: Noémi visszaesett, édesanyja új problémákkal hozakodott elő. Gyanítható volt, hogy a háttérben valamilyen félelem húzódhat meg. Az aggodalmat kiváltó narratívájuk könnyen kiderült, elég volt rákérdezni, hogy mitöl tartanak: egy sikeres kezelés után is könnyen visszaesés következhet be (ez éppen megtörtént), és az édesanya a támaszát érezte elveszíteni. Csak feltételezhetjük, hogy az intervenciónk melyik eleme járult hozzá az elválási probléma sikeres megoldásához.

Először is szóba jöhet az, hogy a kimondatlan félelmetes narratíva nyílt megfogalmazása önmagában is fontos volt. A terápiás kapcsolatot mélyítette.

Másrészt a narratíva lényegére adekvát megoldást ajánlottunk: nem kell elválnunk egymástól, a találkozások számát édesanya kontrollálhatja - bár nem hetente, hanem 3 hetente.

Noémi prognózisát tudatosan a pozitív tapasztalatok folytatásaként alkottuk meg, számítva ennek szuggesztív hatására. Azt akartuk elérni, hogy egy esetleges visszaeséshez az anya ne katasztrofizáló jelentést konstruáljon. 
Az esettel azt kívántuk szemléltetni, hogy sok probléma hátterében a kliens egy kimondatlan narratívája lehet. Ezt gyakran egyszerü módon is fel lehet tárni, és megnyugtató választ találva a probléma megoldható.

\section{2. esetbemutatás}

A klienssel egyéni pszichoterápiás helyzetben találkoztunk. Az eset bemutatásakor a terapeuta és a kliens narratíváira és az externalizációra fókuszálunk.

Egy 36 éves férfi azért keresett meg, mert először 3 hónapja, majd egyre gyakrabban gyors szívveréssel, remegéssel, szédüléssel, zsibbadással, halálfélelemmel járó rohamszerü rosszullétei voltak. Amikor nem volt rohama, akkor attól félt, hogy mikor lesz a következö. Emiatt a vállalkozását csak nagy szenvedés árán tudta felügyelni, emiatt anyagi hátrány is érte már. A szülei és a felesége segítökészen és türelmesen viselték a betegség következményeit. Az élettörténetéből még kiderült, hogy 8 éve folytatta a jelenlegi kereskedelmi vállalkozását, ami nagyon kimerítette. Évek óta nem volt szabadságon, gyakran csak 3-4 órát aludt, fizetési nehézségei voltak, elhúzódó konfliktusa volt a hatóságokkal. Több orvosi vizsgálaton volt túl, mire terápiába jelentkezett. Ezek a vizsgálatok kicsit ingadozó vérnyomást igazoltak, ami azonban a panaszával nem volt összefüggésbe hozható. Más tekintetben szervi eltérés nem volt kimutatható. Pánikbetegséget állapítottak meg, és háziorvosa küldte pszichoterápiára.

A terapeuta narratívái: tapasztalataink alapján a bármilyen ok miatt túlhajszolt, arányaiban felborult életmód vezethet hasonló tünetekhez. A rövid kórtörténet, rendezett család, anyagiak és a betegség előtti jó teljesítmény alapján jó prognózisra, rövid terápiára számítottunk. A terápiás módszer választása kérdésében modernista szemléletet nem akartunk alkalmazni, mert úgy éreztük, hogy ha valamilyen kész elméleti modellbe próbáljuk kliensünk történetét beilleszteni, akkor lehet, hogy a számára legfontosabb dolgoktól eltérítjük a terápiás folyamatot. Ez időveszteség lenne és nem szolgálja a terápiás kapcsolatunkat. Tovább figyeltünk, és rákérdeztünk a saját narratívájára.

A kliens narratívája: számára a fő problémát a pánikbetegség tünetei jelentették. Ha nem lett volna a betegség, folytatta volna a munkáját, úgy és ahol abbahagyta. Mivel beteg volt, ezért nem tudott dolgozni, a problémák csak nőttek, egyre kevésbé látta a betegsége végét, és még betegebb lett emiatt. Ebböl az ördögi körből nem tudott kilépni. Jól érzékelhető a maladaptív narratívákra jellemző kilátástalanság.

Mivel az elsődleges panasza a pánikbetegség volt, a szorongás mögött húzódó halálfélelem egzisztencialista narratíváját beszéltük meg, és kitértünk a halálfélelem csökkentésére szolgáló stratégiákra is. Néhány viselkedésterápiás szorongásoldó manőverre (légzéskontroll, figyelemkontroll) is megtanítottuk, és kilátásba helyeztük a betegsége jó prognózisát. Gyógyszeres kezelést nem igényelt.

A következő alkalommal a szorongás gyengüléséröl számolt be. Ebben visszamenőleg jelentősnek ítélte meg a jó prognózisra vonatkozó megjegyzésünket, valamint a halálfélelmet is a beszélgetés után távolságtartóbban tudta szemlélni. Ez a változás lehetővé tette, hogy kevésbé a tüneteivel foglalkozzunk, hanem további részleteket, érzelmeket ismerjünk meg az életéből. Szerettük volna megfigyelni, hogy milyen meghatározó narratívák vannak a fö életproblémák hátterében. Kiderült, hogy ez a vállalkozás túl nagy terhet jelentett számára. Mostanáig megoldott mindent, de túlságosan stresszelt. Nem szeretett a partnerekkel érintkezni, a hatósági vizsgálatoktól pedig egyenesen rettegett. Viszont abbahagyni sem lehetett, mert tisztességes megélhetést biztosított, és a család már hozzászokott a magasabb életszínvonalhoz. Korábban tanár volt, előrelépésnek tartotta a vállalkozást. A származási családját is ez a feltörekvő szellem hatotta át. Szülei másodállásban gazdálkodtak, öccse vállalkozó háziorvos volt.

A terapeuta narratívája a következőképpen alakult: tehát a kliens a feltörekvő családja narratíváját vallotta magáénak, miszerint a szorgalom, munka, gyarapodás az érték, és ennek 
alá kell rendelni a nyugalmat, arányosságot. Láthatóan a klienst ez nyomasztotta, de nem volt bátorsága szembefordulni ezzel a mélyen a nyugati civilizációban gyökerező domináns narratívával. Az alternatív emberközelibb narratíva alárendelt pozícióban volt, meg sem merte fogalmazni. A terapeuták a helyzetet a domináns narratíva elnyomó hatásaként értelmezték, melynek szükségességét megkérdőjelezhetőnek tartották.

A másik alternatíva lehetett volna az, hogy a kliens megtartja a feltörekvő narratívát, és emellett a terapeuták megtaníthatták volna konfliktuskezelésre, a vállalkozás szerkezetében strukturális változtatásokat beszélhettek volna meg, esetleg még elmehetett volna a kliens valamilyen menedzserképzésre. Várhatóan így kisebb megterhelést jelentett volna a cég vezetése.

Tekintettel arra, hogy a két alternatíva közötti választás a terápia és a beteg sorsának is egy fordulópontja, a terapeuták nem dönthettek, hanem ezt a dilemmát megbeszélték a beteggel. Ö pedig már annyira kiégett a vállalkozásban, hogy az első opciót, a domináns narratíva vizsgálatát választotta.

A domináns narratíva dekonstrukciójának első lépése az externalizálás volt:

Ahogyan figyeljük Önt, amikor a vállalkozásának nehézségeiről beszél, az az érzésünk, hogy az Ön lelkének egy része folyamatosan és kíméletlenül arra kényszeríti Önt, hogy csak csinálja, eröltesse, nem számít, mibe kerül, a vállalkozásának termelnie kell. Mi a véleménye, hogy pontosan látjuk-e ezt mi?

Ebben a mondatban láthatóan egymásra találtunk a klienssel, lelkesen megerősített, hogy igen, pontosan így érzi. Megkértük, hogy adjon a lelke ezen részének egy nevet, hogy tudjunk róla beszélni. A „Törekvés” nevet adta neki. Ettől kezdve minden lehetséges alkalommal a mondat alanya Törekvés volt. Például Törekvés nem hagyta elaludni, amikor túl sokáig dolgozott éjszaka. A házi feladata is az volt, hogy Törekvés hangját vegye észre a gondolataiban, és írja le, ügyelve Törekvés alanyiságára.

A későbbi beszélgetések alatt a Törekvés sugallta gondolatok és cselekedetek beazonosítása után Törekvés kialakulásának körülményeiről beszélgettünk, Törekvés céljáról, pozitív hatásáról, és arról, hogy mibe került Törekvés - a kliensnek és másoknak. Eljutottunk oda, hogy Törekvés eszköz helyett életcél lett, a kontroll alól kiszabadult, mint egy hajóágyú. Innen már magától következett, hogy Törekvés helyett milyen életcélokról tud gondolkodni, és ehhez milyen feltételeket kell megteremtenie, milyen áron.

Közben a szorongásos tünetek háttérbe szorultak, el is felejtkezett róluk.

A kliens úgy döntött, hogy a vállalkozását értékesíteni fogja, és állást fog keresni.

Ebben az esetleírásban a kliens pánikbetegség tüneteivel jelentkezett, melyet egy kulturálisan mélyen megalapozott feltörekvési narratíva által keltett feszültség következményének minősítettünk. Bemutattuk az externalizáció technikáját, a kliens és a terapeuta narratíváinak kölcsönhatását, a dialektikus fejlödésük folyamatát, melynek eredményeként végül elkészült a közös narratívájuk.

\section{3. esetbemutatás}

Párterápiás kontextusban történt az eset, és a narratívák kiválasztásának felelősségéről szól.

Egy negyvenes éveiben járó házaspár jelentkezett terápiába a feleség házasságon kívüli szerelmi kapcsolata miatt. A pár mindkét tagja diplomás volt, munkahelyükön vezetö beosztást töltöttek be. A munkahely sok idejüket és energiájukat igénybe vette. Két alsó tagozatos gyermekük volt. Az utóbbi években a kapcsolatuk elszürkült, kölcsönösen elhanyagolták egymást, a munka és a gyermekek gondozása töltötte ki az idejüket. A szexuális életük is ellaposodott. Az asszony az új párkapcsolatban megtalálta a boldogságát. Azonban nagy válságba került mindenki, amikor lelepleződött a viszonyuk, és a férje mindent megtett azért, hogy visszaszerezze a feleségét. A terápia során eldőlt, hogy az asszony a családját választja és megszakítja a házasságon kívüli kapcsolatát. A döntést közvetlenül 
követően kapcsolódunk be a terápiába, amikor még a „hogyan tovább” kérdése függőben van. Így még meg kell találniuk az új életük szabályait, megoldást kell találniuk a büntudatra és a megbocsátásra.

A házaspár mindkét tagját megkértük, hogy mondják el, hogyan értelmezik a történteket.

A kérdés jelentése az volt, hogy készítsék el a krízisük narratíváját, azaz adjanak magyarázatot arra, hogy mi miért történt. Ez a jelentésadás nagy fontosságú volt a jövőre nézve. Nézzünk meg több lehetséges narratívát:

1. Az asszony csapodár természetü, nem tud ellenállni a kísértésnek.

2. A férj alulmaradt riválisával szemben.

3. Egy húsz éves házasság már érzelem nélküli, kiég, gyakran így ér véget másutt is.

4. A kölcsönös érzelmi elhanyagolás vezetett a hütlenséghez, és a külső kapcsolat nyújtott kárpótlást. De a család ereje visszafordította a folyamatot.

Abból a szempontból vizsgáljuk meg a lehetséges narratívákat, hogy milyen utakat nyitnak meg a jövőre nézve!

1. Az asszony csapodár természetével nem lehetett volna mit kezdeni, hacsak nem egy elhúzódó féltékenységi stratégia kidolgozását. Ez nagyon hátrányos lett volna a jövőre nézve.

2. Ha a férj alulmaradt, akkor abból kisebbségi érzés és féltékenység, gyötrődés következik. Kétséges kimenetelü lett volna a férj önbizalmának erősítése. Ez is borús perspektíva.

3. A húsz éves házasság menetrendszerü kiégése szinte normává teszi a hütlenséget és a válást, felmenti a felelősség alól a szereplöket. Sodródást jelent a válás felé.

4. Ha a kölcsönös elhanyagolás következményének tartjuk a krízishelyzetüket, akkor ebböl következik egy program, hogy hogyan ne hanyagolják el egymást a jövöben. Ha a család erejének tulajdonítjuk a folyamat visszafordítását, akkor ezzel a férjet elsősorban, de a feleséget is megerősítjük, hiszen olyan emberekként tünnek föl, akik képesek a családjukért egy ilyen gödörből felküzdeni magukat. Egyúttal a büntudat és a megbocsátás felé is teszünk egy lépést, azáltal, hogy a krízis után jobb lesz a kapcsolatuk, mint előtte volt. Egy végeredményében pozitív hatású cselekedetért miért kellene megbocsátani, illetve büntudatnak lenni? Ez persze nem ilyen egyszerü, lehet ok a büntudatra, de ez a narratíva mindenképpen könnyíti a megbocsátás és a büntudat feldolgozását is.

Az eset követését itt nem folytatjuk, mert csak a narratívák fontosságát akartuk demonstrálni. Lépjük át a párterápia kontextusát, mert az eset tanulságai minden segítő kapcsolatban, sőt a magánéletben is érvényesek.

Láthatóan több lehetséges alternatív értelmezés is szóba jöhet, bár erre a gyakorlatban nem mindig gondolunk. Nagy felelösség, hogy az érintett személy átgondolja a lehetséges értelmezéseket és megfelelően válasszon. A fenti példákból az következik, hogy az a jó narratíva, amelyik valamilyen járható utat kínál a megoldás felé. Amelyik előrevisz. Aki azokat a narratívákat választja, amelyek nem kínálnak megoldásokat, felelőssé válik a saját kudarcaiért.

Felmerül az a kérdés, hogy bár nyilván számít, hogy milyen megoldásokat kínál egy narratíva, de melyik narratíva az igaz? Ebben a helyzetben az igazság nem látszik egy jól használható fogalomnak több szempontból sem. Először is ritkán fordul az elö, hogy egy fontos döntésnek egyetlen magyarázata lenne. Az „,igazság” tehát az okok között egy százalékos megoszlás lenne.

Másrészt kérdéses az is, hogy a több szereplő közül kinek az ,igazságáról” beszélünk? Kinek-kinek az események során változik a személyisége, és korábbi véleményét már saját 
maga is érthetetlennek tartja. Akkor ilyen esetben melyik időpontban érvényes „,igazságát” vesszük tekintetbe?

Ha a megoldás érdekében a felek úgy döntenek, hogy függetlenül a ,igazságtól” egy előrevivő értelmezést választanak, akkor az a narratíva meg fogja határozni a tetteiket és valósággá válik. Az eredeti ,igazságuk” csak egy lépcsőfoknak nevezhető, mely a megoldáshoz vezetett.

Természetesen a narratív szemlélet alapján sem lehet a múltat meg nem történtté tenni, a felelősséget elkenni, de a megoldás felé mutató narratívákat lehet mérlegelni.

A segítő helyzetben a terapeuta felelősséget vállalhat abban, hogy a kliensekben a narratívák közötti választás lehetőségét tudatosítsa.

\section{Konklúziók}

A gyorsan változó társadalomhoz a segítő kapcsolatnak is alkalmazkodnia kell. A posztmodern narratív szemlélet sok vonása mutat ebbe az irányba. A valóság mentális reprezentációját szubjektív konstrukcióknak tartja, ugyanígy a társadalom domináló diskurzusait, például az értékrendet, a divatot, a hagyományokat is. A konstrukciós jelleg lényegéből fakad, hogy mindezek megkérdőjelezhetőek, bár az emberek ezeket jellemzően evidenciaként élik meg. A narratív szemlélet a konstrukciók átalakíthatóságában látja a beavatkozás lehetöségét.

A legegyszerübb narratívák könnyen kommunikálhatók, megválaszolhatók, lezárhatók, ha gondolunk rá. A mélyen gyökerező, csak részben tudatos narratívák már nagyobb erőfeszítés révén, a nyelv lehetőségeit felhasználva dekonstruálhatók.

A narratív szemléletű segítő intervenciók viszonylagos gyorsaságát és rugalmasságát az adja, hogy szorosan a kliens aktuális problémájához illeszkednek, személyre szabottak. Újszerü vonásuk, hogy a segítőt partneri szerepbe helyezik, akinek a saját narratíváival ugyanúgy feladata van, mint a klienséivel.

Tekintettel arra, hogy a szemlélet a valóság sokféle értelmezésének szabadságát támogatja, különösen fontos mind a kliensnek, mind a segítöjének a saját és a mások sorsáért viselt fokozott felelösséget észben tartania.

\section{Irodalom}

Bálint, M. (1990). Az orvos, a betege és a betegség. Budapest: Animula Egyesület.

Bókay, A. (2006). Bevezetés az irodalomtudományba. Budapest: Osiris Kiadó.

Crystal, D. (2003). A nyelv enciklopédiája. Budapest: Osiris Kiadó.

Goldenberg, H. és Goldenberg, I. (2008). Áttekintés a családról. Budapest: Animula Kiadó.

Hawking, S. és Mlodinov, L. (2011). A nagy terv Budapest: Akkord Kiadó.

Kecskeméti Molnár, M. (2004). Narratív terápia * bemutató és ajánlás Új-Zélandból. Pszichoterápia, 13, 366-376.

László, J. (2005). A történetek tudománya. Budapest: Új Mandátum Könyvkiadó.

Launer, J. (2002). Narrative-based Primary Care. Abingdon, Egyesült Királyság: Radcliffe Medical Press.

O’Connor, J. és Seymour, J. (1996). NLP. Piliscsaba: Bioenergetic Kft.

Payne, M. (2014). Narratív terápia. Budapest: Magyar Családterápiás Egyesület.

Prochaska, J. O. és Norcross J. C. (2011). A pszichoterápia rendszerei. Budapest: Animula Kiadó.

Schulz von Thun, F. (2012). A kommunikáció zavarai és feloldásuk. Budapest: Háttér Kiadó. Tillich, P. (2002). Rendszeres teológia. Budapest: Osiris Kiadó. 
Tolcsvai Nagy, G. (2002). Szójelentés. In Sipos, L. (szerk.), A magyar nyelv és irodalom enciklopédiája (pp. 112-115) Budapest: Magyar Könyvklub.

Wilber, K. (2009). A müködő szellem rövid története Budapest: Ursus Libris Bt.

Yalom, I.D. (1978). Egzisztenciális pszichoterápia. Budapest: Animula Kiadó. 